\title{
Influence of Geomechanical and Hydraulic Parameters of the Fractured Rock on the Evolution of Underground Karst Cavities in Cheria Area, NE Algerea
}

\author{
Chamekh Khemissi ${ }^{1}$, Djemmal Samir ${ }^{2,}$, Boukhalfa Adel $^{3}$, Baali Fethi ${ }^{1}$ \\ ${ }^{1}$ Laboratory of Water and Environment, Department of Geology, Chiekh Larbi Tebessi University, Tebessa, Algeria \\ ${ }^{2}$ Mobilization and Management Laboratory of Water Resources, Department of Geology, El Hadj Lakhdar University, Batna, Algeria \\ ${ }^{3}$ Laboratory of Physical Properties of Materials, Department of Metallurgy, Badji Mokhtar University, Annaba, Algeria
}

\section{Email address:}

Geologie84@gmail.com (C. Khemissi),samirgeol@yahoo.fr (D. Samir), adelboukhalfa28@yahoo.com (B. Adel),

Baali_fr2000@yahoo.fr(B. Fethi)

${ }^{*}$ Corresponding author

\section{To cite this article:}

Chamekh Khemissi, Djemmal Samir, Boukhalfa Adel, Baali Fethi. Influence of Geomechanical and Hydraulic Parameters of the Fractured Rock on the Evolution of Underground Karst Cavities in Cheria Area, NE Algerea. American Journal of Water Science and Engineering. Vol. 4, No. 2, 2018, pp. 23-27. doi: 10.11648/j.ajwse.20180402.12

Received: January 13, 2018; Accepted: June 12, 2018; Published: July 24, 2018

\begin{abstract}
The main goal of this study is to analyze the surface part of the karst and some underground characteristics of Eocene karst system. The Karst cavities are widespread in the Eocene forming the upper formation under the Quaternary cover in the Cheria syncline. Therefore, the karstfied zone requires new methods for estimating average depth of the karts cavities from structural, geometrical, and mechanical properties of fractured rock. In that way, statistical methods is very efficient for describing in detail the shallow part of karst cavities, when Eocene limestone outcrops at the surface in the center and northern of the basin. A stochastic analysis is carried out to evaluate the influence of correlations between relevant distributions on the simulated RMR values, also to simulate the cavity depth. The model is also used in Monte Carlo simulations. The statistical analysis showed that Rock Mass Rating (RMR) depends on the hydraulically and geomechancal parameters. Naturally it is always possible to simulate a cavity depth (PKR) by several hydraulically and geometrical parameters of fractures (uniaxial compressive strength; RC), Rock Quality Designation (RQD), Spacing fracture $\left(E_{J}\right)$, inflow per 10 tunnel length $\left(D_{10 \mathrm{~m} . \mathrm{L}}\right)$, friction cording of the angle of the rock mass $\left(\mathrm{C}_{\mathrm{D}-\mathrm{I} . \mathrm{j}}\right)$, layer depth $(\mathrm{Pc})$, average aperture to each group of the fracture $\left(\mathrm{d}_{\mathrm{i}}\right)$, average fracture frequency to each group of the fracture $\left(f_{i}\right)$, fracture depth $\left(\mathrm{df}_{\mathrm{i}}\right)$ ), especially in the case of $k$ non real fracture geometry. The study of the relations between geomechanical fractured rock and fracture geometry, we can simulate any cavity depth (PRK) in Chera syncline.
\end{abstract}

Keywords: Fractures, Karst, Cavities, Simulation, Cheria, Algeria

\section{Introduction}

The Karst cavities are widespread in the Eocene forming the upper formation under the Quaternary cover in the Cheria syncline [1].

This study focuses on utilizing stochastic fracture network to simulate of the karst cavities depth in the Eocene limestone. The later forming the upper formation under the quaternary cover and it occupy more than $80 \%$, the resting $20 \%$ are composed of the Mio-plio quaternary filling deposits in the Cheria syncline. The geometric fracture network can be simulated by the experimental equation for determine indirectly the karst cavities depth. The Eocene limestone aquifer is intensively fractured and karstified. Major sub surface karst cavities is located nourthen and centre part of Cheria syncline. Hence, cavity roof thickness are varied with geometrical and geomchanical parameters on the fractured rock [2]. The depth of the karstified zones depends on the geomechanical parameters, which is controlled by the fracture aperture distribution [3]. 


\section{Study Areas}

The study site at Cheria is situated $45 \mathrm{~km}$ south western of Tebessa in Algeria. It is a syncline structure. It is a wide plateau of a triangular shape, covering of around $720 \mathrm{~km}^{2}$. The altitudes vary from 985 to $1700 \mathrm{~m}$.

\section{Geological and Hydrogeological Setting}

Incidence on karstic hydrology: In the Cretaceous formations of the Cheria province, in which are located aquifers systems of karstic type [4]. On two images we superimposed a square of tracing paper, on which we report the lineaments that appeared in the (Figure 1). The basin is affected by many different tectonic phases and neotectonic movement. Fractures orientations are dominantly found in $\mathrm{NE}$ to SW and NW to SE cut by a sub-orthogonal third set of $\mathrm{N}$ to $\mathrm{S}$.

These data compared with observations of some subsurface karstic phenomena (karstified fractures) makes it possible to propose a diagram for the evolution of the preferential directions of karstifications (orientations $\mathrm{N} 40$ and $\mathrm{N} 140$ principally) [5].

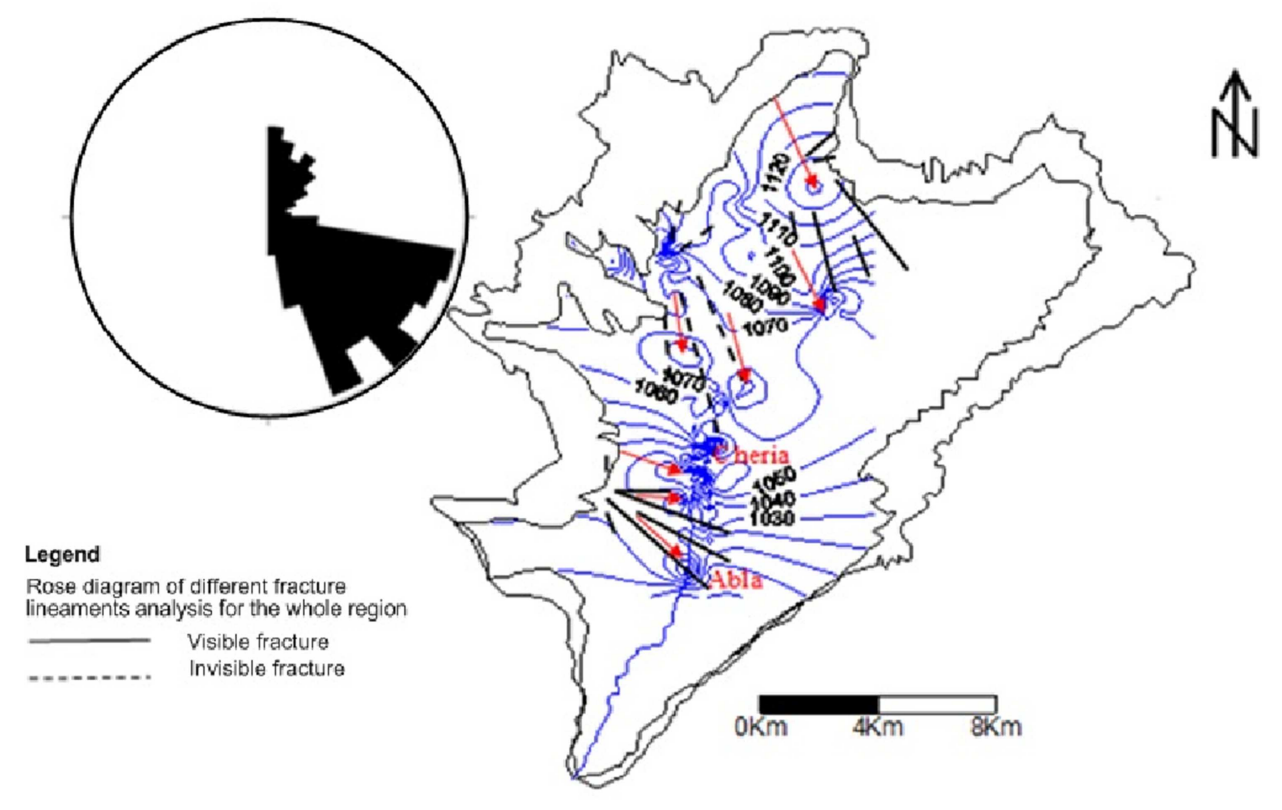

Figure 1. Relationships of fractures mapped from the air

The results gathered from rose diagram, had put in evidence four significant groups; they have been classed according to their order of importance as followed: the 1st group $130-140 \mathrm{E}$; the 2nd group $100-110 \mathrm{E}$; the 3rd group $40-50 \mathrm{E}$; the 4 th group $0 \mathrm{E}$.

Generally fractures are underlain by zones of localized weathering and increased permeability and porosity [6].

The contour Map of the study area showing groundwater flow direction in two dimensions for Eocene limestone aquifer. The thickness of the Eocene limestone aquifer increases towards the central part of the basin [7]. Flow pattern of the Eocene limestone aquifer system in study area revealed that groundwater flow direction was toward the South and south eastern parts of the area guided by the fractures and the preferential directions of the karst cavities. Its represent concentrations of void space in rocks. The geometry of the void space affects both the flow properties and the karst cavities depth, such as the geomechanical parameters and characterizing hydraulically.

\section{Fracture Characterization and Measurement}

The Eocene limestone aquifer is intensively fractured and karstified. The wells drilled for underground water extraction show that voids were encountered at the depth between 1 to 40 $\mathrm{m}$. Structural data about fault and fracture systems have been collected from both surface and subsurface survey, using in the latter case the extended net of explored karst caves. The fracture network can be described by the areal and vertical extent, the spacing or density of individual fractures, and the orientation distribution [8]. This information can be used to assess the physical connections between individual fractures, which influence kars cavities depth. Many workers [9] contend that the spacing of joints is proportional to the thickness of the fractured layer as displayed by the field data in.

The Fracture frequency is the number of fractures occurring within a unit length. The number of natural fractures is divided by the length and is reported as fractures 
per foot or fractures the average frequency over a section perpendicular to one the fracture, for three groups, is $\mathrm{f}_{1}=$ $0.725 \mathrm{f} / \mathrm{m}, \mathrm{f}_{2}=2.282 \mathrm{f} / \mathrm{m}, \mathrm{f}_{3}=1.25 \mathrm{f} / \mathrm{m}$. The aperture is the perpendicular distance separating the adjacent rock walls of an open discontinuity, it is increase with depth of the fractured rock, in which the intervening space is air or waterfilled, the average aperture of the fracture system is $d_{1}=0.028$ $\mathrm{m}, \mathrm{d}_{2}=0.0173 \mathrm{~m}, \mathrm{~d}_{3}=0.0116 \mathrm{~m}$.

\section{Cavity Depth Simulated by Fracture Geometry}

The reason is that in Cheria, underground cavities exist in varying dimensions, from one metre to more than $40 \mathrm{~m}$ across.

They also occur at a depth less than a meter to several tens of meters with varying rock mass properties. Hence, cavity roof thickness are varied with geometrical and geomchanical parameters of the fractured rock.

For rock properties uniaxial compressive strength (RC), Rock Quality Designation (RQD), Rock Mass Rating (RMR). They were determinate as we are dealing with fractured rock mass.

The karst cavities depth will be simulated with geometrical properties karst cavities in study area (Figure 2), the underground cavities covered by a mantle of varying thickness constituted of a mixture of graved sand, clays and limestone crusts in the centre of the Cheria syncline. However, from small troughs on northern and on either side.

Over large temporal and spatial scales morphometric of karst cavities is governed by a number of complex processes and factors: closed water level to the surface, thickness of the Mio-Plio Quaternary filling deposits (Cqua), roof thickness (ET), karst cavities (RK), cavity depth (PKR), We can consider here that the PKR equals ET plus RK $(\mathrm{PKR}=\mathrm{ET}+$ RK) (Figure 3).

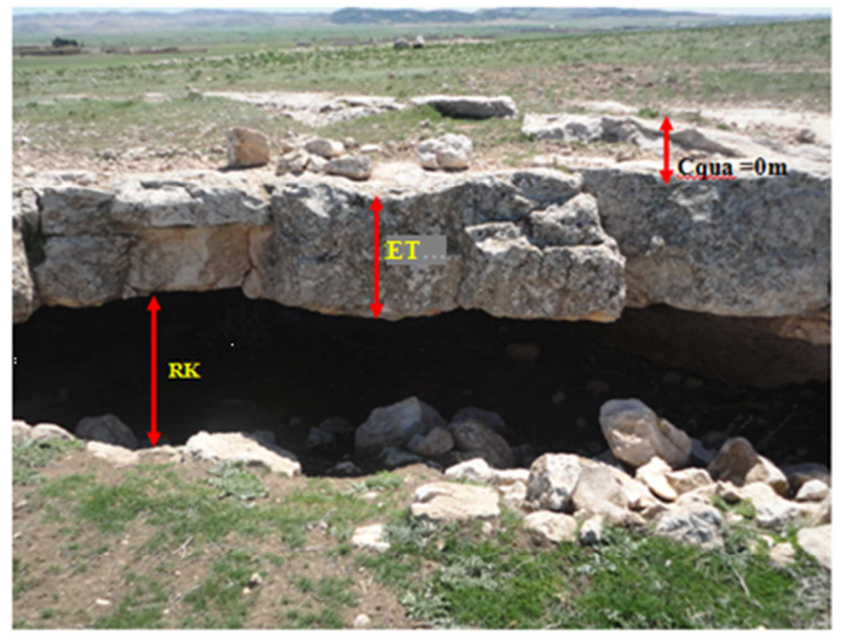

Cqua: Mio-Plio Quatemary filling deposits.

RK: karst cavities

PRK: Cavity depth

Figure 2. Morphometric the shallow part of the karst cavities.

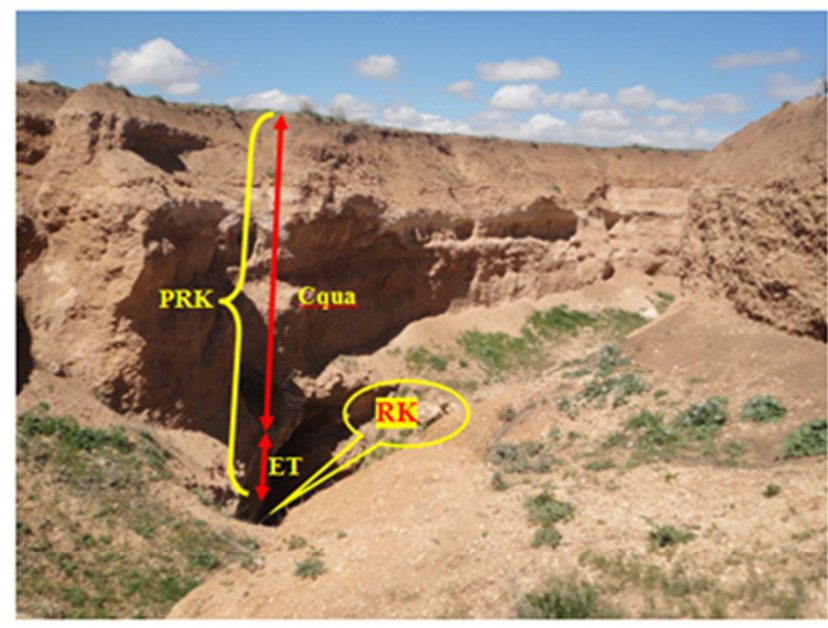

Cqua: Mio-Plio Quatemary filling deposits

PRK : Cavity depth

RK: karst cavities

ET : Roof thickness

Figure 3. Morphometric of the underground cavities covered by Mio-PlioQuaternary.

\section{Methods of Field Investigation}

Method of field investigation can be classified into the broad types: 2D and 3D. The 2D methods are based on observations made at the rock surface, at surface or subsurface levels.

They included scanline surveys and different types of areal surveys. These methods give an idea of geomechanical and hydrogeological properties at and around the site of observation. The 3D methods are aimed at gathering information on the bulk volumetric properties involving inner structure of the fractured rock mass.

An accurate Observations and measurements carried out on the field from ten sites, which is located at the centre and northern periphery of the Cheria syncline, epikarst features such as cheminies, pinnacles and cavities are well exposed.

The flowing geomechanical parameters were determined: uniaxial compressive strength (RC), Rock Quality Designation (RQD), Spacing fracture $\left(\mathrm{E}_{\mathrm{J}}\right)$ is related to lithology and thickness of the bed (Price and Cosgrove 1990), inflow per 10 tunnel length $\left(\mathrm{D}_{10 \mathrm{~m} . \mathrm{L}}\right)$, friction cording of the angle of the rock mass $\left(\mathrm{C}_{\mathrm{D}-\mathrm{Ij}}\right)$, layer depth $(\mathrm{Pc})$, fracture depth $\left(\mathrm{Pf}_{\mathrm{i}}\right)$, average dip to each group of the fracture $\left(\mathrm{d}_{\mathrm{i}}\right)$, average aperture to each group of the fracture $\left(\mathrm{d}_{\mathrm{i}}\right)$, average fracture frequency to each group of the fracture $\left(f_{i}\right)$, Rock Mass Rating RMR. These latter are developed by several authors and Bieniawski (1973) [10]. Then, these distributions are included as inputs in the Rock Mass Rating (RMR) classification system prepared in a spreadsheet model. A stochastic analysis is carried out to evaluate the influence of correlations between relevant distributions on the simulated RMR values, also to simulate the cavity depth.

The model is also used in Monte Carlo simulations. The proposed approach provides a straight forward and effective assessment of the variability of the rock mass properties. Hence, a wide array of mechanical characteristics can be adequately represented in any preliminary design 
consideration for a given rock mass [11].

\section{Results and Discussion}

The available data were based upon laboratory and field work. Table 1 shows the necessary hydraulically and geomechanical properties of the fractured Eocene limestone of Cheria area (average values of the site number five) assumed for mathematical model.

Table 1. Measured hydraulically and geomechanical properties of the Eocene limestone.

\begin{tabular}{|c|c|c|c|c|c|c|c|c|}
\hline Pe () & Rc (Mpa) & & RQD (\%) & $\mathrm{Ej}(\mathrm{m})$ & & $\mathbf{D}_{10 \mathrm{ml}}$ & $C_{\text {D-I-J }}$ & \\
\hline 5 & 83.23 & & 60 & 0.5 & & 24 & -5 & \\
\hline $\begin{array}{l}\text { Fracture } \\
\text { group } 1\end{array}$ & & & group 2 & & & group 3 & & \\
\hline $\mathrm{d}_{1}(\mathrm{~m})$ & $\mathrm{f}_{1}(\mathrm{f} / \mathrm{m})$ & $\mathrm{Pf}_{1}()$ & $\mathrm{d}_{2}(\mathrm{~m})$ & $\mathrm{f}_{2}(\mathrm{f} / \mathrm{m})$ & $\mathrm{Pf}_{2}()$ & $\mathrm{d}_{3}(\mathrm{~m})$ & $\mathrm{f}_{3}(\mathrm{f} / \mathrm{m})$ & $\mathrm{Pf}_{3}()$ \\
\hline 0.003 & 4.5 & 90 & 0.004 & 1 & 90 & 0.05 & 0.5 & 60 \\
\hline
\end{tabular}

The statistical analysis showed that Rock Mass Rating (RMR) depends on the hydraulically and geomechancal parameters. Naturally it is always possible to simulate a Rock Mass Rating (RMR) by several hydraulically and geometrical parameters of fractures, especially in the case of $\mathrm{k}$ non real fracture geometry. Now, we divide the ground water basin into regions with different Rock Mass Rating (RMR). So, the data processing indicates that Rock Mass Rating (RMR) is given by the following equation:

$$
R M R=0.08218 R c+0.3311 R Q D-11.003 E_{j}+0.3843 D_{10 m . L}-2.5911 C_{D-I J}
$$

The problem of estimating the cavity depth in fractured and karstified aquifers is approached within the framework of a conceptual diagram showing the relationship between fractures geometry, hydrogeologic parameters (aquifer properties and boundary condition), distribution of voids and geological factors Autoregulation between evolution of the underground karst cavities and karst proprieties, duality of karst, nested model of geological discontinuities, scale effect on hydraulic parameters and use of statistical methods to check the interpretations of the global response of the karst.
If we have $\mathrm{N}$ fracture systems, in each system, there being $\mathrm{f}$ fractures per meter.

However, $\mathrm{Pf}_{\mathrm{i}}$ and $\mathrm{f}_{\mathrm{i}}$ and $\mathrm{d}_{\mathrm{i}}$ being dimension less depending only on the geometrical parameters of fissuring.

The study of the relations between geomechanical fractured rock and fracture geometry led us to simulate any cavity depth (PRK) in Cheria syncline. According to the statistical analysis of experimental data, the cavity depth (PRK) defined as the following empirical equation:

$$
P R K=-1.4246 R M R-0.5926 P c-0.0892 \sum P f_{i}+210.99150 \sum d_{i}-6.5439 \sum f_{i}+127.3546
$$

Substitution of the first empirical equation in the second equation and rearranging the terms we obtain

$$
\begin{aligned}
& P R K=-1.17 R c-0.47 R Q D+15.67 E_{J}-0.55 D_{10 m . l}+3.69 C_{D . J}-0.5926 P c-0.0892 \sum P f_{i}+ \\
& +210.99150 \sum d_{i}-6.5439 \sum f_{i}+127.3546
\end{aligned}
$$

Where

$\mathrm{Rc}=$ Uniaxial compressive strength (MPa)

$\mathrm{RQD}=$ Rock Quality Designation (\%)

$\mathrm{Ej}=$ Spacing fracture $(\mathrm{m})$

$\mathrm{D}_{10 \mathrm{~m} . \mathrm{L}}=$ Inflow per 10 tunnel length $(1 / \mathrm{min})$

$\mathrm{C}_{\mathrm{D}-\mathrm{IJ}}=$ Friction cording of the angle of the rock mass

$\mathrm{Pf}_{\mathrm{i}}=$ Fracture depth ()

$\mathrm{Pc}=$ Layer depth ()

$\mathrm{d}_{\mathrm{i}}=$ Aperture of the fractured $(\mathrm{m})$

$\mathrm{f}_{\mathrm{i}}=$ Fracture frequency $(\mathrm{f} / \mathrm{m})$

The cavity depth can be calculated from geomechanical and hydraulically parameters, assuming the following hypothesis:

$\mathrm{H}_{1}$ : Mio-plio-quaternary filling deposits less than $9 \mathrm{~m}$ (Cqua $<9 \mathrm{~m}$ ),

$\mathrm{H}_{2}$ : Group number of the fracture upper than $2(\mathrm{I} \geq 3)$

$\mathrm{H}_{3}$ : Fissures are planes and continuous in an elementary volume.

Consequently we can simulate cavity depth by certain geomechanical parameters in a heterogeneous, anisotropic field. In fact we can say that the quantitative relationships represented by the mathematical formula can be used as, interpolation functions for indirect estimation of the cavity depth.

\section{Conclusion}

The results in this study can be generalized to underground cavities of karstic aquifers. In that way, statistical methods is very efficient for describing in detail the shallow part of karst cavities, when Eocene limestone outcrops at the surface in the center and northern of the basin. The study of the relations between geomechanical fractured rock and fracture geometry led us to simulate any cavity depth (PRK) in Cheria syncline. It seems particularly useful for determining vulnerability characteristics as well as geotechnical properties or for positioning boreholes. 


\section{References}

[1] Baali, F., Fehdi, C., Rouabhia, A., Mouici, R., Carlier, E., 2015 "Hydrochemistry and isotopic exploration for a karstic aquifer in a semi-arid region: case of Cheria Plain, Eastern Algeria." Carbonates Evaporites (2015) 30:99-107. DOI 10. 1007/s13146-014-0214-5.

[2] Chamekh, K., Baali, F., Yahiaoui, A., Kerboub, D., 2017 "Hydrogeological setting of a karstic aquifer in a semi-arid region: a case from Cheria plain, Eastern Algeria." Carbonates Evaporites DOI 10. 1007/s13146-017-0400-3.

[3] Renshaw, C. E. 1995. "On the relationship between mechanical and hydraulic apertures in rough-walled fractures. Journal of Geophysical Research." 100: DOI: 10. 1029/95JB02159. ISSN: 0148-0227.

[4] Benhammadi, H., Chaffai, H. 2017 "Climate and human impact on the Karstic environment in the semi-arid zone of the Chéria plateau (Northeast of Algeria)". ISSN: 2220-6663 (Print) 2222-3045 (Online). Vol. 11, No. 4, p. 146-151.

[5] Chamekh, K. 2014. "Relation fracturation-morphologie implications hydrogéologiques. Exemple des calcaires fissures de la région de Chéria (NE Algérien)." Larhyss Journal, ISSN 1112-3680, n 18, pp. 19-30.
[6] Djemmal, S., Menani M. R., Chamekh, K., Baali, F. 2017. "The contribution of fracturations in the emergence of the thermal springs in Setif city, Eastern Algeria." Carbonates Evaporites DOI 10. 1007/s13146-017-0375-0.

[7] Chaffai, H., and al. 2003. "Evaluation des ressources en eaux de la plaine de Chéria (NE Algérie). Synthèse et analyse des données." Doctorat 3ème cycle, USTL, Montpellier II, $245 p$.

[8] Kiraly, L. 1971. "Groundwater flow in heterogeneous, anisotropic fractured media: a simple tow-dimensional." Electric analog. Geological Institute, Neuchtatel, Switzerland. Journal of Hydrolog 12, pp255-261.

[9] Ladiera. 1981. "Rock Fractures and Fluid Flow: Contemporary Understanding and Applications." Washington, DC: The National Academies Press.

[10] Bieniawski, Z. T. 1973. "Engineering classification of jointed rock masses. Transaction South African Institute Cicil Engineers, 15, 335-343."

[11] Price, Cosgrove. 1990. “Analysis of Geological." University Press - Science - 502 page. 